Brian Dobreski, Syracuse University

\title{
Authority and Universalism: Conventional Values in Descriptive Catalog Codes
}

\begin{abstract}
Every standard embodies a particular set of values. Some aspects are privileged while others are masked. Values embedded within knowledge organization standards have special import in that they are further perpetuated by the data they are used to generate. Within libraries, descriptive catalog codes serve as prominent knowledge organization standards, guiding the creation of resource representations. Though the historical and functional aspects of these standards have received significant attention, less focus has been placed on the values associated with such codes. In this study, a critical, historical analysis of ten AngloAmerican descriptive catalog codes and surrounding discourse was conducted as an initial step towards uncovering key values associated with this lineage of standards. Two values in particular were found to be highly significant: authority and universalism. Authority is closely tied to notions of power and control, particularly over practice or belief. Increasing control over resources, identities, and viewpoints are all manifestations of the value of authority within descriptive codes. Universalism has guided the widening coverage of descriptive codes in regards to settings and materials, such as the extension of bibliographic standards to non-book resources. Together, authority and universalism represent conventional values focused on facilitating orderly social exchanges. A comparative lack of emphasis on values concerning human welfare and empowerment may be unsurprising, but raises questions concerning the role of human values in knowledge organization standards. Further attention to the values associated with descriptive codes and other knowledge organization standards is important as libraries and other institutions seek to share their resource representation data more widely.
\end{abstract}

\section{Introduction}

Cataloging is the knowledge organization activity through which libraries create and maintain representations of information resources. Descriptive catalog codes, formal compilations of rules prescribing specific descriptive elements, guide this activity, and over the past 175 years, the Anglo-American descriptive cataloging tradition has been dominated by a relatively small number of codes. Though the historical and functional aspects of these standards have received significant attention, less focus has been placed on the values associated with such codes. Seen as enduring beliefs in preferable modes of conduct of states of existence (Rokeach 1968), values have been shown to be imbricated within standards in significant and influential ways (Bowker and Star, 2000; Lampland and Star, 2009). Values embedded within knowledge organization standards have special import: they are further perpetuated by the knowledge representation data these standards are used to generate. Through the use of linked data technologies, libraries and other cultural heritage institutions look towards an increasing dissemination and integration of their resource representations on the web. As data born from descriptive codes moves beyond the confines of the library catalog, it is increasingly important to understand the values it may be carrying with it as well as the implications for users.

Value analysis represents a systematic approach to revealing the presence and extent of underlying values within content (White 1951). As a research strategy it typically involves content analysis or critical analysis and has been applied to a variety of resources, usually in an attempt to determine an author's values (White 1949), the 
Brian Dobreski. 2017. Authority and Universalism: Conventional Values in Descriptive Catalog Code. NASKO, Vol. 6. pp. 1-11.

values of fictional characters (Lester 1982), or the values associated with a resource itself (Spiggle 1986). Within library and information science, analyses of values frequently focus on professional statements of values (Shachaf 2005; Da Silva et al. 2015), leaving information standards in this area currently unexplored. There exists no single, de facto classification of values for use in value analysis, rather, value theorists and researchers have categorized values in a variety of ways (Rescher 1969). One such classification, derived from cognitive psychology, differentiates among three major types of values: human or moral values focused on well-being, conventional values that facilitate orderly social exchanges, and individual personal values (Smetana 1983; Turiel 1983). This general classification has been previously applied within information systems (Friedman 1997), and is similarly useful in approaching the library domain given its mixture of human and social elements. In fact, examination of library and information science has revealed the field's overarching emphasis on human values (Bates 1999; Gorman 2015; Koehler 2015). In exploring values associated with the cataloging profession, both Bair (2005) and Beghtol (2008) present a number of human values as well. However, as library knowledge organization standards, the extent to which descriptive catalog codes actually embody these asserted values is not fully understood.

In this study, I present the results of a critical, historical analysis of ten AngloAmerican descriptive catalog codes and key surrounding discourse taken as an initial step toward uncovering influential values associated with this lineage of standards. In particular, two conventional values, authority and universalism, emerge as highly influential, and are discussed at length, along with further implications for descriptive codes and knowledge organization standards in general. These findings provide a starting point for further investigation into values and descriptive codes, offer new insight into knowledge organization standards and data, and contribute to the larger body of work on values and value analysis.

\section{Method}

Through consultation of foundational library knowledge organization texts (Joudrey et al. 2015; Chan and Salaba 2016), I identified ten prominent descriptive catalog codes used by Anglo-American libraries. Chronologically, codes ranged from Panizzi's Rules for the Compilation of the Catalogue (1841) to Resource Description and Access (RDA) (Canadian Library Association et al., 2010). Functionally, through their successive adoption and replacement, these codes represent more of a lineage than a body of competing standards. The full list of codes consulted is presented in Table 1. In addition to the texts of these standards, I identified surrounding discourse in the form of contemporaneous secondary sources. These sources included significant works from the library and information science and knowledge organization literature that commented on a specific code, or descriptive codes in general. This literature was confined to the same time period as the consulted codes (1841 to present). The body of secondary sources consulted was not intended to be exhaustive, but rather exemplary, with efforts made to identify works of particular relevance or notability. 
Brian Dobreski. 2017. Authority and Universalism: Conventional Values in Descriptive Catalog Code. NASKO, Vol. 6. pp. 1-11.

Table 1. Descriptive catalog codes consulted

\begin{tabular}{ll}
\hline Date & Title \\
\hline 1841 & Rules for the Compilation of the Catalogue \\
\hline 1852 & On the Construction of Catalogues of Libraries \\
1876 & Rules for a Printed Dictionary Catalogue \\
\hline 1908 & Catalog Rules: Author and Title Entries (AA) \\
\hline 1941 & ALA Catalog Rules: Author and Title Entries \\
\hline 1949 & Rules for Descriptive Cataloging in the Library of Congress \\
\hline 1949 & ALA Cataloging Rules for Author and Title Entries, $2^{\text {nd }}$ Ed. \\
\hline 1967 & Anglo-American Cataloging Rules (AACR) \\
\hline 1978 & Anglo-American Cataloging Rules, $2^{\text {nd }}$ Ed. (AACR2) \\
\hline 2010 & Resource Description and Access (RDA) \\
\hline
\end{tabular}

Through a process of close reading, the standards and secondary sources were subjected to a critical analysis (Griffin 2013); particular focus was given to passages denoting valuation (i.e. the preference of a mode or end state over another). I did not utilize a pre-established list of values in this study; instead, values were considered inductively in order to emphasize the most relevant, situational values over heuristically determined ones (Le Dantec et al. 2009). Values identified during the analysis were organized into the framework of human/moral values, conventional values, and individual values (Smetana 1983; Turiel 1983). However, due to the nature of the present study, individual values were not considered.

During analysis, little evidence of human values was uncovered. As such, I was unable to form these particular findings into a coherent structure at this time. However, many traces of conventional values were found. Through a process of collapsing and condensing, I arrived at two major conventional values: authority and universalism.

\begin{abstract}
Authority
Integral to definitions of authority is the notion of power, particularly over practice or belief; authority has been described as "the power or right to give orders, make decisions, and enforce obedience" ("Authority, n." 2017). In his Theory of Basic Values, Schwartz explored the role of authority as a value, classifying it with other power values such as wealth and social esteem (Schwartz 2012). Schwartz's power values are generally concerned with control or dominance over people or resources, and emphasize the attainment of such a position within a specific social setting. In particular, authority represents a relational state characterized by socially institutionalized differences in power. Work in library and information science has explored the authoritative nature of libraries in relation to users, including its role as cognitive authority (Wilson 1983), trustworthy institution (McCathieNevile and Méndez 2007), and determinant of relevancy (Andersen and Skouvig 2006). However, authoritative relations also characterize knowledge organization work that occurs within libraries. In particular, knowledge organization standards such as descriptive codes are imbued with a type of authoritative power, designed to yield consistency and control. While an obvious connection between catalog codes and authority exists in the
\end{abstract}


Brian Dobreski. 2017. Authority and Universalism: Conventional Values in Descriptive Catalog Code. NASKO, Vol. 6. pp. 1-11.

procedural concept of authority control, a somewhat broader view must be taken. In exploring the role of authority as a guiding value for catalog codes, three broad expressions of power may be seen: expanding authority over viewpoints, over resources, and over identities.

The development and adoption of catalog code has worked to enforce an increasingly singular viewpoint concerning bibliographic entities and their representation. In creating his On the Construction of Catalogues of Libraries for the Smithsonian, Jewett (1852) aspired to set a national standard, and in order for catalogers at a variety of institutions to use the rules, he designed them in such a way as to minimalize individual judgment. Jewett's and other early codes achieved this in part due to heavy reliance on the resource itself, a practice that Cutter (1876) described as the "cult of the title page" (16) and that privileged the viewpoint of the resource producer (Dunkin 1969; Smiraglia 2009). This kind of legalistic approach (Osborn 1941) would wane through the progression of subsequent Anglo-American codes. The Anglo-American Cataloging Rules, $2^{\text {nd }}$ Ed. (AACR2) and its successor, Resource Description and Access (RDA), both allow important descriptive elements to be provided by external sources, including the web (Joint Steering Committee for the Revision of AACR 2005; Canadian Library Association et al. 2010). However, catalog codes now maintain authority over viewpoints in a more fundamental way. In creating Functional Requirements for Bibliographic Records (FRBR), IFLA sought to offer one model of the bibliographic universe (IFLA Study Group on the Functional Requirements for Bibliographic Records 1998). This model is now heavily incorporated into RDA, and emerging standards such as BIBFRAME also rely on the adoption of an underlying conceptual model. Thus catalog codes and related standards are now imbued with greater ontological authority and work to provide an authorized view of the most basic aspects of descriptive practice.

Over time, catalog codes have functioned to provide increasing power and control over collections of resources. Strout (1956) observed that prior to Cutter, catalogs were seen primarily as a means to identify books, but with the introduction of his objects, Cutter strengthened the notion that catalogs were capable of more. Catalogs, enabled by well-structured and consistent rules, could allow users to skillfully exert command over a body of resources, accessing and utilizing information efficiently and effectively. Wilson (1968) addressed this in his Two Kinds of Power, writing: "To have bibliographic control over a collection of things is to have a certain sort of power over those things" (6). Since Cutter's time, catalog codes have been designed in a way to increasingly enable this kind of power. Through the use of more standardized and comprehensive catalog codes in the latter half of the twentieth century, it was hoped that universal bibliographic control would be achieved, a state in which libraries had bibliographic control over all published information resources worldwide (Kaltwasser 1972). Though this has yet to be realized, contemporary catalog codes such as AACR2 and RDA have been designed to enable control over a widening array of information resources through the provision of increasing amounts of descriptive elements. A related implication is that all things covered under these catalog codes are useful, valuable information resources. Andersen and Skouvig (2006) highlighted the power dynamic of library resource collection: in choosing resources, libraries choose what is relevant and valuable. A similar power dynamic may be found in resource description: 
Brian Dobreski. 2017. Authority and Universalism: Conventional Values in Descriptive Catalog Code. NASKO, Vol. 6. pp. 1-11.

by determining what may be described, catalog codes have the power to legitimize objects as information resources under the purview of the library.

Finally, descriptive codes have been designed to guide the construction and management of records for authors and other agents associated with bibliographic resources. This process, known as authority control, facilitates access to bibliographic descriptions by authorizing preferred forms of names for persons, as well as organizations and families. In addressing this, the earliest codes provided moderate guidance but invoked little regard for a person's own name preference (Jewett 1852; Cutter 1876). Modern standards such as AACR2 or RDA provide more extensive rules on determining preferred names for persons, relying more explicitly on literary warrant and common usage. However, in both codes, other additions must be made to distinguish among persons with the same name, including dates, additional names, or titles. The resulting name may thus differ significantly from the form of name a person uses. The practice of labelling a person with a name they do not publicly use in order to facilitate authority control has been raised as an ethical issue by a number by a number of critics, including Lubetzky (1953) and Olson (2001). This practice has only grown more problematic under RDA. The inclusion and treatment of new elements such as gender (Billey et al. 2014; Thompson 2016) have the potential to provoke further conflict with personal self-identifications. RDA authorizes catalogers to record more personal information than ever before, shifting the focus from names and empowering catalogers and the library as arbiters of identity.

\section{Universalism}

Universalism, or the state of applicability or truth across all contexts or cases, relies upon "the insistence that any principle, rule, standard, or law should hold in every instance to which it is applicable" (Berleant 1998, 69). As a value, universalism is also included among the ten major values in Schwartz's Theory of Basic Values (Schwartz 2012). Here, Schwartz interprets universalism with a more humanistic tone, referring to the preference for general inclusiveness and tolerance, and grouping it with other selftranscendent values. Common to these varying interpretations of universalism are a sense of objectivity and a preference for consistency over relativism. Within library and information science, universalism can be seen as the drive toward broadly and consistently applicable principles, standards, and workflows, and has been described as a significant component of the field at an epistemological level (Budd 1995). Specifically regarding knowledge organization standards, Hoffman (2009) noted that catalog codes have developed over time to be more universal, as opposed to catering to specific contexts. This preference is indeed apparent in reviewing the major AngloAmerican descriptive catalog codes, to such an extent that universalism can be interpreted as a significant guiding value. This valuation of universalism can be seen in the trend toward comprehensiveness, both within the domain of libraries and traditional library materials, and ultimately beyond.

The earliest descriptive codes were designed for the collections and needs of a single library or institution. For instance, Panizzi was tasked with establishing cataloging rules specifically for the British Museum's collection of books. The resulting 1841 Rules for the Compilation of the Catalogue presents a set of 91 rules tailored explicitly 
Brian Dobreski. 2017. Authority and Universalism: Conventional Values in Descriptive Catalog Code. NASKO, Vol. 6. pp. 1-11.

to the British Museum, referencing materials common to the museum such as sermons and almanacs (Panizzi 1841). Similarly, Jewett's On the Construction of Catalogues of Libraries was intended to guide the description of books in the Smithsonian collections; however, Jewett had clear aspirations that other libraries around the country would utilize these rules as well (Jewett 1852). As the nineteenth century progressed, an interest in broader, more generally applicable knowledge organization systems was increasing (Svenonius 2000). This can be seen in Cutter's 1876 Rules for a Printed Dictionary Catalogue. Writing not for a specific library, but rather at the behest of the United States Bureau of Education, Cutter sought to produce a set of rules applicable to a wide range of American libraries, attempting to accommodate for differences by providing several levels of catalog fullness.

By the start of the twentieth century, the era of the single library descriptive codes had come to a close and a new era of increasing scope was beginning. Created in 1908 through the cooperation of American and British library associations, the AngloAmerican Catalog Rules sought to unify descriptive practice among libraries in a number of English-speaking countries. Unfortunately, further international cooperation on descriptive codes would be set back by the outbreak of World War II (Tikku 1983), and the follow up to the 1908 Rules would be published solely for American libraries by the American Library Association in 1941. The harmonization of descriptive practice at an international level was revisited in 1961 when IFLA convened the Conference on Cataloging Principles. The end result was the issuance of the Paris Principles, a statement intended to promote further consistency among cataloging rules, with 53 countries agreeing to work towards revising their national codes accordingly (Joudrey et al. 2015). For American and British libraries, the incorporation of the Paris Principles would take place in the next joint code development, the 1967 AngloAmerican Cataloging Rules (AACR). Aside from attempting to cover the needs of all libraries in the United States and the United Kingdom, AACR included, for the first time in a major descriptive code, rules covering the description of non-book materials. The Anglo-American Cataloging Rules, 2nd Ed (AACR2), continued this pursuit of uniformity among a greater number of libraries and a greater amount of materials.

At the turn of the twenty-first century, descriptive cataloging would enter an era characterized by the strongest push towards universally applicable standards yet. AACR2's successor, Resource Description and Access (RDA) represents an attempt at the widest-reaching descriptive standard ever devised. For the first time, a descriptive catalog code has been designed with the intent of adoption among both English and non-English speaking countries. The text of RDA has been translated into Chinese, Finnish, French, German, Italian, and Spanish, and has been adopted or tested by a number of non-English libraries (Poulter 2012). As a descriptive standard, RDA has also been designed to more greatly appeal to institutions beyond the library domain. Whereas introductory matter for AACR2 explicitly mentions libraries (Joint Steering Committee for the Revision of AACR 2005), the initial purpose and scope passage for RDA notably refrains from the use of this term, instead using the more inclusive "agencies organizing resources" (Canadian Library Association et al. 2010). Finally, RDA attempts to extend coverage even further beyond the traditional domain of books than its predecessors. While AACR offered rules covering six non-book formats, and AACR2 increased this number to ten, RDA covers 23 different content types, including 
Brian Dobreski. 2017. Authority and Universalism: Conventional Values in Descriptive Catalog Code. NASKO, Vol. 6. pp. 1-11.

cartographic datasets, notated movement, and three-dimensional moving images. Under RDA, more institutions and materials are united under the same descriptive code than ever before.

\section{Values in Descriptive Standards}

Authority and universalism can be seen as conventional values, facilitating the functioning of social interactions. Their importance in descriptive catalog codes is reasonable considering that knowledge representation and access can be seen as a highly structured social activity. By placing value on authority, descriptive codes support accuracy and precision in fulfillment of users' information requests. The privileging of universalism has promoted uniformity and interoperability in data among a large number of institutions. Together, authority and universalism work to effect consistency, and ultimately, access; as such, the degree to which these values are terminal (desirable end states in and of themselves) or simply instrumental (useful modes of conduct toward other ends) (Orsi 2015) is yet unclear. Authority and universalism may not be the only ways of achieving access though, and it is also worth considering what is lost when authoritative and universal modes or states are privileged. Under systems of authority control, the library's propagation of a preferred form of name may deprive persons of the authority to control their identities (Olson 2001). Similarly, the institution of broad, bibliographic models and ontologies may pose challenges for library data existing alongside alternative conceptions of the bibliographic universe (Dunsire et al. 2012) or work to override users' perspectives (Shirky 2005). Universalist solutions have faced criticism within the knowledge organization community, particularly in contrast with more specialized alternatives (Schmierer 1989; Hoffman 2009). Smiraglia's (2009) exploration of the bibliocentric nature of cataloging standards and the ensuing potentials for resource misrepresentation is especially applicable.

In contrast to the strong representation of conventional values, fewer traces of human values were found. Human or moral values are concerned with human wellbeing; examples of human values of interest in the information domain include privacy and autonomy (Friedman 1996). The lack of emphasis on human values within descriptive catalog codes may at first appear unsurprising. However, human values have long been considered essential to library and information science (Bates 1999; Gorman 2015; Koehler 2015), making their relative absence in crucial domain standards more curious. In their statement of the core values associated with librarianship, the American Library Association, publisher of numerous catalog codes, presents a list unquestionably dominated by human values such as privacy, diversity, and intellectual freedom (American Library Association 2004). The applicability of this list to cataloging work has been questioned though (Shoemaker 2015), and the apparent mismatching of asserted institutional values with those embedded in key artifacts raises a number of questions. What is the role of human values such as privacy, autonomy, and intellectual freedom in descriptive catalog codes? What role does knowledge organization play in supporting the humanistic goals of the library? What would a more humanistic descriptive standard look like? Further exploration of how human values 
Brian Dobreski. 2017. Authority and Universalism: Conventional Values in Descriptive Catalog Code. NASKO, Vol. 6. pp. 1-11.

manifest in descriptive catalog codes and other knowledge organization standards, as well as the implications of their presence or absence, is warranted.

As the product of descriptive catalog codes and practices, resource representation data is traditionally confronted in the context of the library catalog. However, new approaches in data publishing and dissemination, in line with linked data and other Semantic Web technologies, promise to take library data beyond the confines of the catalog. These advances promise new and exciting uses of descriptive data, but may serve to decontextualize or obscure its origins. What are the implications of transporting data born from descriptive catalog code's particular value system to new and unexpected settings and users? Value sensitive design is one perspective that may be useful in confronting this question. Originally advanced as a methodological framework for upholding key values during technology design (Friedman 1996), value sensitive design approaches have grown to encompass value discovery and analysis as well (Le Dantec et al. 2009). Understanding values associated with technologies and standards, as well as their users, can enable the design and presentation of resource descriptions better aligned with desired institutional and community values. Benefitting from value sensitive design or other such approaches here first requires further investigation into the values associated with descriptive standards and data, as well as how values are embedded in knowledge organization standards in general.

\section{Conclusion}

Descriptive catalog codes serve as prominent knowledge organizing standards in the library domain. Over the past 175 years, Anglo-American cataloging has been guided by a lineage of a small number of prominent codes. As with any standards, descriptive catalog codes have the potential to harbor values embedded within them. In this critical, historical analysis, the conventional values of authority and universalism were found to be particularly influential. The comparative lack of emphasis on human values is worth noting, especially considering the role of human values in the broader domain of library and information science. Further investigation is required to understand how values manifest in catalog codes, as well as the presence and roles of both conventional and human values in knowledge organization standards at large. The values imbricated in catalog codes and the resulting descriptive data have bearing on the broader, online information environment beyond the catalog as libraries look to share and combine their resource representation data through linked data strategies. Continuing attention to values in the design of such data, as well as associated systems and interfaces, is needed.

\section{References}

American Library Association. 1908. Catalog Rules: Author and Title Entries. American edition. Boston, Mass.: American Library Association.

American Library Association. 2004. "Core Values of Librarianship.” American Library Association.

http://www.ala.org/advocacy/intfreedom/statementspols/corevalues 
Brian Dobreski. 2017. Authority and Universalism: Conventional Values in Descriptive Catalog Code. NASKO, Vol. 6. pp. 1-11.

American Library Association. Catalog Code Revision Committee. 1941. ALA Catalog Rules: Author and Title Entries. Chicago, Ill.: American Library Association.

American Library Association, The Library of Congress, The Library Association, and The Canadian Library Association. 1967. Anglo-American Cataloging Rules. North American Text. Chicago, Ill.: American Library Association.

Andersen, Jack and Laura Skouvig. 2006. "Knowledge Organization: A Sociohistorical Analysis and Critique." The Library Quarterly 76: 300-322.

"Authority, n." 2017. OED Online. http://www.oed.com/view/Entry/13349

Bair, Sheila. 2005. "Toward a Code of Ethics for Cataloging." Technical Services Quarterly 23: 13-26.

Bates, Marcia J. 1999. "The Invisible Substrate of Information Science." Journal of the Association for Information Science and Technology 50: 1043-1050.

Beghtol, Clare. 2008. "Professional Values and Ethics in Knowledge Organization and Cataloging." Journal of Information Ethics 17: 12-19.

Berleant, Arnold. 1998. "Leaving Relativism." In Relativism and Beyond, eds. Yoav Ariel, Shlomo Biderman, and Ornan Rotem. Leiden: Brill, 67-87.

Billey, Amber, Emily Drabinski, and K. R. Roberto. 2014. "What's Gender Got to Do with It? A Critique of RDA 9.7." Cataloging \& Classification Quarterly 52: 412421.

Bowker, Geoffrey C., and Susan Leigh Star. 2000. Sorting Things Out: Classification and Its Consequences. Cambridge, Mass.: MIT Press.

Panizzi, Antonio. 1841. "Rules for the Compilation of the Catalogue." In The Catalogue of the Printed Books in the British Museum, vol. 1. London: British Museum, v-ix.

Budd, John M. 1995. “An Epistemological Foundation for Library and Information Science.” The Library Quarterly 65: 295-318.

Canadian Library Association, Chartered Institute of Library and Information Professionals (Great Britain), Joint Steering Committee for Development of RDA, and American Library Association. 2010. RDA Toolkit: Resource Description \& Access. http://www.rdatoolkit.org/

Chan, Lois Mai, and Athena Salaba. 2015. Cataloging and Classification: An Introduction. 4th ed. Lanham, Md.: Rowman \& Littlefield.

Cutter, Charles Ammi. 1876. Rules for a Printed Dictionary Catalogue. Washington, D.C: US Government Printing Office.

Da Silva, Andrieli Pachú, José Augusto Chaves Guimarães, and Natália Bolfarini Tognoli. 2015. "Ethical Values in Archival Arrangement and Description: An Analysis of Professional Codes of Ethics." Knowledge Organization 42: 346-352.

Division of Cataloging and Classification of the American Library Association. 1949. ALA Cataloging Rules for Author and Title Entries. 2nd ed. Chicago, Ill.: American Library Association.

Dunkin, Paul Shaner. 1969. Cataloging U.S.A. Chicago, Ill.: American Library Association.

Dunsire, Gordon, Diane Hillmann, and Jon Phipps. 2012. "Reconsidering Universal Bibliographic Control in Light of the Semantic Web." Journal of Library Metadata 12: 164-176.

Friedman, Batya. 1996. "Value-Sensitive Design.” Interactions 3, no. 6: 16-23. 
Friedman, Batya. 1997. Human Values and the Design of Computer Technology. Cambridge: Cambridge University Press.

Gorman, Michael. 2015. Our Enduring Values Revisited: Librarianship in an EverChanging World. Chicago, Ill.: ALA Editions.

Griffin, Gabriele, ed. 2013. Research Methods for English Studies. 2nd ed. Edinburgh: Edinburgh University Press.

Hoffman, Gretchen L. 2009. "Meeting Users' Needs in Cataloging: What is the Right Thing to Do?" Cataloging \& Classification Quarterly 47: 631-641.

IFLA Study Group on the Functional Requirements for Bibliographic Records. 1998. Functional Requirements for Bibliographic Records: Final Report. Munich: K.G. Saur.

Jewett, Charles Coffin. 1852. On the Construction of Catalogues of Libraries, and their Publication by Means of Separate, Stereotyped Titles: With Rules and Examples. Washington, D.C.: Smithsonian Institution.

Joint Steering Committee for the Revision of AACR. 2005. Anglo-American Cataloguing Rules. $2^{\text {nd }}$ ed., 2002 rev., 2005 update. Chicago, Ill.: American Library Association.

Joudrey, Daniel N., Arlene G. Taylor, and David P. Miller. 2015. Introduction to Cataloging and Classification. $11^{\text {th }}$ ed. Santa Barbara, Calif.: Libraries Unlimited.

Kaltwasser, Franz George. 1972. "The Quest for Universal Bibliographical Control." Wilson Library Bulletin 46: 894-901.

Koehler, Wallace. 2015. Ethics and Values in Librarianship: A History. Lanham, Md.: Rowman \& Littlefield.

Lampland, Martha and Susan Leigh Star, eds. (2009). Standards and Their stories: How Quantifying, Classifying, and Formalizing Practices Shape Everyday Life. Ithaca, NY: Cornell University Press.

Le Dantec, Christopher A., Erika Shehan Poole, and Susan P. Wyche. 2009. "Values as Lived Experience: Evolving Value Sensitive Design in Support of Value Discovery." In Proceedings of the SIGCHI Conference on Human Factors in Computing Systems. New York: ACM, 1141-1150.

Lester, Nancy B. 1982. “A System for Analyzing Characters' Values in Literary Texts." Research in the Teaching of English 16: 321-338.

Library of Congress. Descriptive Cataloging Division. 1949. Rules for Descriptive Cataloging in the Library of Congress. Washington, D.C.: Library of Congress, Descriptive Cataloging Division.

Lubetzky, Seymour. 1953. Cataloging Rules and Principles: a Critique of the A.L.A. Rules for Entry and a Proposed Design for Their Revision. Washington, D.C.: Processing Dept., Library of Congress.

McCathieNevile, Charles, and Eva Méndez. 2007. "Library Cards for the 21st Century." Cataloging \& Classification Quarterly 43, nos. 3-4: 21-45.

Olson, Hope A. 2001. "The Power to Name: Representation in Library Catalogs." Signs: Journal of Women in Culture and Society 26: 639-668.

Orsi, Francesco. 2015. Value Theory. New York: Bloomsbury Publishing.

Osborn, Andrew D. 1941. "The Crisis in Cataloging." The Library Quarterly 11: 393411. 
Brian Dobreski. 2017. Authority and Universalism: Conventional Values in Descriptive Catalog Code. NASKO, Vol. 6. pp. 1-11.

Poulter, Alan. 2012. "The 'Europeanisation'of Cataloguing Codes: An Analysis of the Evolution of RDA." In Library and Information Science Trends and Research: Europe, eds. Amanda Spink and Jannica Heinström. Bingley: Emerald, 67-84.

Ranganathan, S. R. 1931. The Five Laws of Library Science. Madras: The Madras Library Association.

Rokeach, Milton. 1968. Beliefs, Attitudes and Values: A Theory of Organization and Change. San Francisco: Jossey-Bass Inc.

Schmierer, Helen F. 1989. "The Impact of Technology on Cataloging Rules.” In The Conceptual Foundations of Descriptive Cataloging, ed. Elaine Svenonius. San Diego: Academic Press, 101-116.

Schwartz, Shalom H. 2012. "An Overview of the Schwartz Theory of Basic Values." Online Readings in Psychology and Culture 2, no. 1. http://dx.doi.org/10.9707/2307-0919.1116

Shachaf, Pnina. 2005. "A Global Perspective on Library Association Codes of Ethics." Library \& Information Science Research 27: 513-533.

Shirky, Clay. 2005. "Ontology is Overrated: Categories, Links, and Tags.” Clay Shirky's Internet Writings. http://www.shirky.com/writings/ontology_overrated.html

Shoemaker, Elizabeth. 2015. "No One Can Whistle a Symphony: Seeking a Catalogers' Code of Ethics." Knowledge Organization 42: 353-357.

Smetana, Judith G. 1983. "Social-Cognitive Development: Domain Distinctions and Coordinations." Developmental Review 3, no. 2: 131-147.

Smiraglia, Richard P. 2009. "Bibliocentrism, Cultural Warrant, and the Ethics of Resource Description: A Case Study." Cataloging \& Classification Quarterly 47: 671-686.

Spiggle, Susan. 1986. "Measuring Social Values: A Content Analysis of Sunday Comics and Underground Comix." Journal of Consumer Research 13: 100-113.

Strout, Ruth French. 1956. "The Development of the Catalog and Cataloging Codes." The Library Quarterly 26: 254-275.

Svenonius, Elaine. 2000. The Intellectual Foundation of Information Organization. Cambridge, Mass.: MIT Press.

Thompson, Kelly J. (2016). "More Than a Name: A Content Analysis of Name Authority Records for Authors Who Self-Identify as Trans." Library Resources \& Technical Services 60: 140-155.

Tikku, Upinder Kumar. 1983. “Anglo-American Cataloging Rules, 1908-1978: A State of the Art." Annals of Library Science and Documentation 30, nos. 3-4: 151-165.

Turiel, Elliot. 1983. The Development of Social Knowledge: Morality and Convention. Cambridge: Cambridge University Press.

White, Ralph K. 1949. "Hitler, Roosevelt, and the Nature of War Propaganda." The Journal of Abnormal and Social Psychology 44, no. 2: 157-174.

White, Ralph K. 1951. Value-Analysis: The Nature and Use of the Method. Glen Gardner, N.J.: Libertarian Press.

Wilson, Patrick. 1968. Two Kinds of Power: An Essay on Bibliographical Control. Berkeley, Calif.: University of California Press.

Wilson, Patrick. 1983. Second-Hand Knowledge: An Inquiry into Cognitive Authority. Westport, Conn.: Greenwood Press. 